\title{
\#MeToo is Changing the Game for Startups
}

\section{Kimberly Eddleston (Northeastern University)}

KEYWORDS: Entrepreneurship, Legal, Women, human resources.

The \#MeToo era has created new challenges for entrepreneurs and startups. Cautionary tales abound of startups whose hard-partying culture resulted in sexual harassment, hostile work environments and high costs to their reputations and finances. New businesses today have both a mandate and an opportunity to build a workplace that not only complies with laws against sexual harassment, but also makes every employee feel respected, safe and comfortable. EIX's Kim Eddleston recently explored this topic with Leona Barsky, an attorney and consultant to small and medium-sized businesses on sexual harassment and gender equity. The U.S. Equal Employment Opportunity Commission (https://www.eeoc.gov/employers/smallbusiness/faq/ind ex.cfm) has additional useful information about this subject.

Additional search terms: \#MeToo, MeToo, me too, \#me too, women, feminism, female founders, women business owners, glass ceiling, sexual discrimination, sexual harassment, bias, opportunity 